\title{
Economic Impact of Tourism Accommodation: Thailand
}

\author{
Pornpen Vora-Sittha ${ }^{1}$ \\ ${ }^{1}$ Center for AEC Capability Research, Nation Institute of Development Administration (NIDA), Thailand \\ Correspondence: Pornpen Vora-Sittha, Director of Center for AEC Capability Research, Nation Institute of \\ Development Administration (NIDA), Thailand. E-mail: pornpen_econ@yahoo.com
}

Received: April 20, $2016 \quad$ Accepted: May 17, $2016 \quad$ Online Published: June 21, 2016
doi:10.5539/ass.v12n7p222
URL: http://dx.doi.org/10.5539/ass.v12n7p222

\begin{abstract}
Accommodation plays a significant role in tourism infrastructure; without a reliable place to stay overnight, tourists will not visit the location. Aligning with concepts described in the 2008 Tourism Satellite Account: Recommended Methodological Framework (TSA: RMF 2008), accommodation services are among 12 tourism sectors which are interrelated with each other through flow-on activities. When accommodation establishments purchase goods and services through their day-to-day transaction and pay their workers, this money is recirculated through the economy. Therefore, this study examined the impacts of expenditure spent by the visitors for accommodation on the economy both directly and indirectly. The Leontief Input-Output Model for the twelve tourism sectors was developed to calculate the impacts of tourist spending on lodging and other interrelated tourism services in Thailand. Data used in this study are from both primary and secondary sources. Findings indicated that tourism accommodation in Thailand was the second largest contributor to the tourism industry after "Air passenger transport services". The computed multiplier showed that linkages of services between accommodation services providers and other tourism sectors helped generate income for the economy higher than the direct income paid directly from the tourists.
\end{abstract}

Keywords: low case, comma, paper template, abstract, keywords, introduction

\section{Introduction}

\subsection{Why Tourism Accommodation Is Important?}

Motivation to travel usually leads to the desire to experience a wider tourism product at a particular resort or locality. Even though accommodation by itself does not attract tourists; it provides services that are the core element of the tourism industry, and thus be one of the important tourism products which play a significant role in the tourism sector. It forms a base for the tourist's exploration of the urban and non-urban environments, without it, tourists will hardly visit the location. Tourist accommodation provides the opportunity for visitors to stay for a length of time to enjoy the locality and its attractions while their spending contributes to the local economy. Therefore, it can be a tool for generating income for the tourism industry as well as the nation.

For Thailand, tourism is one of a significant income contributor for the economy. In 2013, Thailand was the $10^{\text {th }}$ "top tourist destination" in the world tourism rankings with 26.5 million international arrivals (UNWTO, 2014). The rising number of arrivals pushed up the high demand for travel accommodation.

Even though accommodation sector is significant in generating income for Thailand, no study measures the impacts of such increased economic activity, either in a country as a whole or a region or even a local destination. This paper provides a quantitative method to estimate the economic benefits that the tourism accommodation industry brings to the economies and other related tourism sectors.

\subsection{Review of Previous Study}

Thailand's reliance on international tourism ranks as number 2 in ASEAN and the 18th in the world (WTTC, 2014). The increasing number of tourists arouses demand for accommodation in Thailand. Euromonitor International (2014) estimated that travel accommodation sales rise at an annual growth rate of $4.73 \%$ during 2009-2018 and amount to $2.57 \%$ of total GDP in 2014 while the forecast of travel accommodation outlets is at $2.87 \%$ per year.

There is considerable interest in measuring the impacts of increased economic activity in tourism, either for a country as a whole or a region or even a local destination. Such effects can be estimated by using the data from 
Tourism Satellite Account (TSA), combined them with other types of instruments such as Computable General Equilibrium Models, Models based on Input-output analysis, and Multipliers.

Currently, there are quite some countries such as the United States of America, Canada, Australia, and the European Union have followed the framework of The Tourism Satellite Account: Recommended Methodological Framework 2008 (the TSA: RMF 2008) in organizing their tourism data. For Thailand, the Tourism Satellite Account (TSA) namely TSA-Thailand (NIDA, 2013) has been developed by Watanakuljrus, Vora-Sittha, \& Silaprachawong (2014), and the data established will be used in this study.

Aligning with concepts described in the 2008 Tourism Satellite Account: Recommended Methodological Framework (TSA: RMF 2008), there are altogether 12 typical tourism products drawn up by the UNWTO and the OECD. Accommodation services are one of them, as shown in Table 1. The Leontief Input-Output Model of the twelve tourism sectors for Thailand was constructed to calculate the impacts of tourist spending on lodging and other inter-related tourism services for Thailand in this study.

Table 1. The twelve products and activities of tourism characteristic categorized in the 2008 tourism satellite account

\begin{tabular}{ll}
\hline \multicolumn{1}{c}{ Products } & \multicolumn{1}{c}{ Activities } \\
\hline 1. Accommodation services & 1. Accommodation for visitors \\
2. Food and beverage serving services & 2. Food and beverage serving activities \\
3. Road passenger transport services & 3. Road passenger transport \\
4. Shopping products & 4. Shopping \\
5. Railway passenger transport services & 5. Railway passenger transport \\
6. Water passenger transport services & 6. Water passenger transport \\
7. Air passenger transport services & 7. Air passenger transport \\
8. Travel agencies and other reservation services & 8. Travel agencies and other reservation services activities \\
9. Transport equipment rental services & 9. Transport equipment rental \\
10. Cultural services & 10. Cultural activities \\
11. Sports and recreational services & 11. Sports and recreational activities \\
12. Others (Country-specific tourism characteristic & 12. Others (Country-specific tourism characteristic \\
services ) & activities) \\
\hline
\end{tabular}

Source. Eurostat (2008), Figure 3.1.

WTTC (2014) has produced reports and forecasts the economic and employment impact of Travel \& Tourism for 184 countries and 25 geographic or economic regions in the world including Thailand. From the Report, the direct contribution of Travel \& Tourism to GDP for Thailand was 32.4 billion USD (7.3\% of total GDP), and the total contribution of Travel \& Tourism to GDP was 75.8 billion USD (17.1\% of total GDP) in 2015. The report did not show the impact of tourist accommodation or any other sectors to GDP as presented in this study.

\section{Method}

\subsection{The Data}

Table 2. Selected tourist attraction provinces for the survey

\begin{tabular}{llll}
\hline Region & & Selected Provinces & \\
\hline The Capital & Bangkok & & \\
The North & Chiangmai & Chiangrai & Phisanuloke \\
The Central Plan and the West & Prachuap Khiri Khan & Phetchaburi & Kanchanaburi \\
The North-east & Nakhon Ratchasima & Khon Kaen & Udon Thani \\
The East & Chonburi & Rayong & Trad \\
The South & Phuket & Surat Thani & Krabi \\
\hline
\end{tabular}

Note. The Sample size conducted in each province is 700 for the internal visitors, and 100 for the main business persons in each region. 
Data used in this study are from both primary and secondary sources. For the primary data, a quota sampling survey was conducted from 5 regions of Thailand, with altogether 11,200 questionnaires for internal tourists and 600 key business persons from the focus group in 16 targeted provinces. Except Bangkok, three provinces which generated the average highest annual income, during 2007-2009, from tourism in each region were selected as targeted area (Table 2). The observations cover the 12 tourism sectors as presented in Table 1 in each province. The secondary data are partly from Input-output of Thailand 2005 and the National Income of Thailand 2013. The two sources of data are used to develop the "Tourism I-O Table for Thailand (NIDA 2013)".

\subsection{The Measurement of the Economic Contribution}

The "Tourism I-O Table for Thailand (NIDA 2013)" for the twelve tourism sectors was developed to calculate the impacts of tourist spending on lodging and other inter-related tourism services for Thailand. Measurement of the economic benefits of tourists' payment on accommodation and other related tourism sectors will be presented regarding the net increase in the wealth of residents resulting from tourist spending for accommodation, in monetary terms, and over and above the levels that would prevail in its absence. The increased in income will partly come from payment of tourists in exchange for shelter services (direct effect), and partly from the indirect demand. When the accommodation service provider recirculates the money to other related tourism sectors of the economy such as food and beverage, transportations, entertainment, souvenirs, in exchange for the services received from them.

Technically, the use of Input-output model for this study is suitable for analyzing economic impact from accommodation spending on the economy. Unlike general industry, tourism consumption includes elements that do not belong to final demand but to intermediate consumption of activities developed by resident producers. The Input-output model embeds Inter-industry data which help determine how are effects in one industry will impact other sectors. Besides, the models also estimate the share of each industry's purchases that are supplied by local firms. Based on this data, multipliers are calculated and used to assess economic impacts.

Direct effects derive from the initial spending which creates additional activity in the local economy. Indirect effects, on the other hand, are the results of business-to-business transactions which indirectly caused by the direct effects, businesses that are initially benefiting from the direct effects will subsequently increase their spending to other local businesses, and hence generate indirect effect from this increase in business-to-business activity.

Also, induced effects are the results of increased personal income caused by the direct and indirect effects; businesses experiencing increased revenue from the direct and indirect effects will subsequently increase payroll expenditures (by hiring more employees, increasing payroll hours, raising salaries.). Households will, in turn, increase spending at local businesses. The induced effect is a measure of this change in household-to-business activity (Weisbrod \& Weisbrod, 1997).

In this study, the computation is confined to only direct effect and indirectly effect of income generating within the tourism sector in Thailand. The induced effect is the results which link tourism industry to outside tourism activities will not be presented. The TSA Framework (TSA: RMF 2008) only take into consideration tourism direct contribution to Gross Value Added or Gross Domestic Product in the economy.

\section{Results}

\subsection{Internal Tourism in Thailand}

Internal tourism comprises of domestic and inbound tourism. It includes the activities of resident and non-resident visitors within Thailand as part of local or international trips. The domestic tourism in Thailand reaches 95.0 million trips in 2013, whiles the foreign arrivals witness new record of 26.7 million trips, with a growth rate of $5 \%$ and $19 \%$ respectively. The International tourism in Thailand was crowded by visitors from China, Malaysia, Russia, Japan and South Korea respectively, with the share of $45.9 \%$ of the total inbound arrival, and 40.0 of the total receipts from foreign tourists (Euro monitor, Thailand; 2014).

Among the 16 tourism attraction provinces, Bangkok was the top destination for both Thai and inbound visitors (Table 3). For foreign arrivals, Bangkok and Phuket are the most visit provinces. For domestic arrivals, their destination is rather scattered all over the country; most of them decide to travel not just for only leisure purpose but also to visit their family or relations in the different areas.

The visitor normally includes excursionist (same day visitor) and tourists who stay overnight. It is the tourist that relates to accommodations service for their travels. For the whole kingdom, the ratio of tourist to excursionist for domestic tourism is only 1.39 , as shown in Table 3 , whiles for inbound tourism the ratio is 6.22 , indicating that accommodation sector is still advantageous from rising tourists in Thailand. For locations with more tourist 
attractions, the proportion of the international tourist to the excursion ones for the 16 provinces is 14.40 , much higher than the country average. Kanchanaburi and Petchaburi are the two provinces which are the least attractive for staying overnight for both Thai and foreigners.

Table 3. Traveling destinations for internal visitor in Thailand

\begin{tabular}{|c|c|c|c|c|c|}
\hline \multirow{2}{*}{ Destination } & \multicolumn{3}{|c|}{ Percentage of Visitor* } & \multicolumn{2}{|c|}{ Ratio of Tourist to Excursionist } \\
\hline & Thai & Foreigner & Total & Domestic & Inbound \\
\hline Bangkok & 19.78 & 33.55 & 22.81 & 1.60 & 15.69 \\
\hline Chiangmai & 2.94 & 4.23 & 3.22 & 2.70 & 9.90 \\
\hline Chiangrai & 1.47 & 0.95 & 1.36 & 7.14 & 6.79 \\
\hline Phisanuloke & 1.56 & 0.35 & 1.29 & 1.50 & 3.11 \\
\hline Surat Thani & 1.09 & 4.89 & 1.92 & 6.61 & 60.71 \\
\hline Phuket & 2.20 & 15.16 & 5.05 & 12.75 & 22.26 \\
\hline Krabi & 1.09 & 3.60 & 1.64 & 5.74 & 7.92 \\
\hline Udon Thani & 1.79 & 0.25 & 1.45 & 2.42 & 1.25 \\
\hline Khon Kaen & 2.18 & 0.11 & 1.73 & 1.91 & 1.96 \\
\hline Nakhon Ratchasima & 4.13 & 0.23 & 3.27 & 1.36 & 2.53 \\
\hline Kanchanaburi & 3.74 & 0.66 & 3.06 & 0.59 & 0.74 \\
\hline Phetchaburi & 3.06 & 0.78 & 2.56 & 0.85 & 2.57 \\
\hline Prachuap Khiri Khan & 2.16 & 1.65 & 2.05 & 1.31 & 6.04 \\
\hline Chonburi & 2.80 & 13.03 & 5.04 & 2.18 & 48.42 \\
\hline Rayong & 3.20 & 0.86 & 2.68 & 1.47 & 4.10 \\
\hline Trad & 0.79 & 0.73 & 0.78 & 20.51 & 15.04 \\
\hline Total of 16 Provinces & 53.98 & 81.02 & 59.93 & 1.72 & 14.40 \\
\hline Whole Kingdom ('000)** & 94,960 & 26,759 & 121,719 & 1.39 & 6.22 \\
\hline
\end{tabular}

Source. * Thailand Tourism Authority, ** Euromonitor (2014)

\subsection{Tourism Accommodation Structure}

Most of the existing studies in tourism put their focus on hotels as tourist accommodations, ignoring the fact that there are numerous classifications of accommodation facilities related to the tourism industry. Hotels constitute proportion as a sub-sector of tourism accommodation business. Euromonitor International (2014) classified accommodation into "Hotel" and "Other Travel Accommodation." Among the sale values of ten world tourist attractions countries, hotels contributed significantly in nearly all countries except Australia and South Korea (Table 4).

Upon comparing "Chained hotel" and "Independent hotel" among the ten countries studied, the "Chained hotel" in six out of ten countries including Thailand earned a bigger share of travel accommodation sales than the "Independent hotel." The sales performance of hotels in Thailand dominated by the chained hotel, driven by international companies; such as Accor Group, Marriott International Inc, and Starwood Hotels \& Resorts Worldwide Inc. A group of the chained local hotel is few, but the performance is quite impressive. Included in this group are Asia Hotel Co, Ltd, Dusit Thani PCL, Central Plaza Hotel PCL,. International chained hotels usually located in prime locations such as beautiful beaches or centrally in the city while local hotel group covers more areas in the country.

The "Other travel accommodation" comprises of motels, guesthouses, campsites,..., as shown in Table 4. This type of accommodation become significant in South Korea and Australia; where the motels in Korea play the biggest share, and in Australia, the private accommodation earns the highest sale among other travel accommodation.

For Thailand, "Other travel accommodation" is very fragmented and seems to be popular in provincial and rural areas. Guesthouses tend to be popular with western arrivals who wish to experience the Thai style of living which provides a comfortable place for hospitality at an affordable price. Regarding income, self-catering apartment and motel seemed to be the top earner among other travel accommodation type for Thailand (Table4). 
Table 4. A Comparison of travel accommodation sales and outlets among tourist attraction countries in 2013

\begin{tabular}{|c|c|c|c|c|c|c|c|c|c|c|}
\hline & Thailand & Malaysia & Philippines & Vietnam & Japan & S. Korea & Hong Kong & Australia & France & Russia \\
\hline & \multicolumn{10}{|c|}{ Percentage of Travel Accommodation Sales by Category (2013) } \\
\hline Hotels & 78.11 & 90.97 & 94.16 & 99.27 & 59.72 & 20.63 & 96.92 & 43.91 & 66.24 & 76.96 \\
\hline - Chained Hotels & 54.06 & 68.31 & 55.65 & 21.80 & 16.77 & 12.36 & 54.24 & 38.27 & 24.83 & 36.07 \\
\hline - Independent Hotes & 24.05 & 22.65 & 38.51 & 77.47 & 42.95 & 8.26 & 42.68 & 5.64 & 41.41 & 40.89 \\
\hline Other Travel Accommodation & 21.89 & 9.03 & 5.84 & 0.73 & 40.28 & 79.37 & 3.08 & 56.09 & 33.76 & 23.04 \\
\hline - Campsites & 0.07 & 0.05 & 0.00 & 0.00 & 0.37 & 1.79 & 0.00 & 9.71 & 8.72 & 0.11 \\
\hline - Chalets & 0.00 & 1.60 & 0.00 & 0.01 & 0.30 & 0.78 & 0.00 & 2.62 & 3.09 & 0.00 \\
\hline - Guesthouses & 4.38 & 0.77 & 0.79 & 0.02 & 1.31 & 0.19 & 2.94 & 2.45 & 1.93 & 3.52 \\
\hline - Hostels & 0.16 & 0.55 & 0.46 & 0.00 & 0.04 & 0.26 & 0.00 & 2.19 & 0.23 & 1.01 \\
\hline - Motels & 1.86 & 0.18 & 1.26 & 0.08 & 0.00 & 68.75 & 0.00 & 9.71 & 0.00 & 0.91 \\
\hline - Private Accommodation & 0.71 & 0.21 & 0.18 & 0.00 & 0.01 & 6.56 & 0.14 & 17.82 & 10.50 & 1.27 \\
\hline - Self-Catering Apartments & 10.71 & 5.34 & 0.53 & 0.00 & 0.02 & 0.35 & 0.00 & 4.30 & 8.28 & 0.59 \\
\hline - Other Travel Accommodation & 4.00 & 0.34 & 2.62 & 0.62 & 38.23 & 0.69 & 0.00 & 7.28 & 1.02 & 15.62 \\
\hline \multirow[t]{2}{*}{ Travel Accommodation } & 100.00 & 100.00 & 100.00 & 100.00 & 100.00 & 100.00 & 100.00 & 100.00 & 100.00 & 100.00 \\
\hline & \multicolumn{10}{|c|}{ Travel Accommodation Outlets in Units (2013) } \\
\hline Travel Accommodation & 16,721 & 4,148 & 6,938 & 13,794 & 83,857 & 44,562 & 1,235 & 49,606 & 494,064 & 38,330 \\
\hline Hotels & 6,784 & 2,752 & 915 & 13,489 & 9,847 & 710 & 226 & 2,542 & 17,042 & 4,839 \\
\hline Other Travel Accommodation & 9,937 & 1,396 & 6,023 & 305 & 74,010 & 43,852 & 1,009 & 47,064 & 477,022 & 33,491 \\
\hline
\end{tabular}

Source. Euromonitor International, Travel Accommodation in Thailand, December 2014.

There is a tendency that the "Chained hotel" will still be the largest player in the accommodation sector in Thailand in the future. The Euro Monitor (2014) forecasts that the average growth rate of "Chained hotel" is average at $6 \%$ in the next five years (2514-2018); the fastest one compared to other types of accommodation (Table 5).

Table 5. Growth rate of travel accommodation sales in Thailand by category (\%)

\begin{tabular}{|l|r|r|r|r|r|r|r|r|r|r|r|}
\hline & 2010 & 2011 & 2012 & 2013 & $2014^{*}$ & $2015^{*}$ & $2016^{*}$ & $2017^{*}$ & $2018^{*}$ & $2014-2018$ \\
\hline Hotels (1) & 4.19 & 5.89 & 5.36 & 6.19 & 4.85 & 5.13 & 5.39 & 5.69 & 5.97 & 5.40 \\
\hline - Chained Hotels & 4.00 & 6.30 & 5.70 & 6.50 & 5.00 & 5.50 & 6.00 & 6.50 & 7.00 & 6.00 \\
\hline - Independent Hotes & 4.60 & 5.00 & 4.60 & 5.50 & 4.50 & 4.30 & 4.00 & 3.80 & 3.50 & 4.02 \\
\hline Other Travel Accomm. (2) & 2.51 & 2.93 & 3.01 & 3.94 & 1.89 & 2.03 & 2.20 & 2.32 & 2.44 & 2.18 \\
\hline - Campsites & 2.98 & 2.80 & 3.01 & 4.01 & 1.99 & 2.40 & 2.69 & 3.00 & 3.20 & 2.66 \\
\hline - Guesthouses & 2.50 & 3.40 & 3.60 & 4.50 & 1.80 & 1.70 & 1.60 & 1.50 & 1.40 & 1.60 \\
\hline - Hostels & 1.37 & 4.40 & 2.99 & 3.99 & 2.00 & 2.21 & 2.50 & 3.00 & 3.20 & 2.58 \\
\hline - Motels & 1.50 & 2.60 & 2.80 & 4.00 & 2.00 & 2.20 & 2.30 & 2.40 & 2.60 & 2.30 \\
\hline - Private Accommodation & 2.65 & 3.46 & 4.40 & 3.80 & 1.80 & 2.00 & 2.30 & 2.46 & 2.74 & 2.26 \\
\hline - Self-Catering Apartments & 2.44 & 2.81 & 2.80 & 3.50 & 1.80 & 2.00 & 2.30 & 2.50 & 2.70 & 2.26 \\
\hline - Other Travel Accomm. & 3.17 & 2.79 & 2.80 & 4.50 & 2.20 & 2.40 & 2.50 & 2.60 & 2.70 & 2.48 \\
\hline Travel Accommodation (1+2) & 3.80 & 5.20 & 4.83 & 5.69 & 4.20 & 4.47 & 4.72 & 5.00 & 5.27 & 4.73 \\
\hline
\end{tabular}

Note. * Estimate from Euromonitor International, Travel Accommodation in Thailand, December 2014, Table 8.

\subsection{How Much do Tourists Spend for Accommodation Services in Thailand?}

According to our primary survey, expenditure for accommodation services per head per trip for Thailand is average at 8,200 baht (263.8 USD). Domestic tourists pay less amount of money for lodgings than foreign arrivals, since Thai people have less number of holiday days per year, and pay the much less moderate 
accommodation cost than foreign tourists on the average (Table 6). Also, the number of stay overnights for the whole kingdom were 4.17 days for foreign tourists and 2.7 days for Thai visitors. (Vora-Sittha, Silapachawong, \& Watanakuljarus, 2015).

Among the 16 selected tourism attraction provinces, the cost of shelter varies from two thousand baht to more than ten thousand baht. Phuket and Krabi provinces are the most expensive destinations to stay overnight. The cheap cost of accommodation services appear in some less attractive tourism area in the west (Kanchanaburi and Phetchaburi), northeast (Udon Thani, Khon Kaen, and Nakhon Ratchasima) and some province in the north regions (Phisanuloke). For the well-known city like Bangkok, the capital of Thailand, it is found that the expenditure per head per trip for accommodation are rather moderate compared to Phuket and Krabi surrounded by sea and sand in the Southern region. However, as the top destination in Thailand for tourists, accommodation in Bangkok always earns the largest share ever. (Table 6).

Table 6. A comparison of expenditure per person per trip and income derived from accommodation by provinces

\begin{tabular}{|c|c|c|c|c|c|c|}
\hline \multirow{2}{*}{ Location } & \multicolumn{3}{|c|}{ Expenditure Per Head Per Trip (baht) } & \multicolumn{3}{|c|}{ Direct Income from Visitor } \\
\hline & Thai Tourist & Foreign Tourist & Total tourist & Thai visitor & Foreign vistor & Total visitor \\
\hline Bangkok & 6,617 & 18,092 & 10,328 & 124,280 & 162,412 & 286,693 \\
\hline Chiengmai & 6,822 & 7,537 & 7,029 & 19,019 & 8,528 & 27,547 \\
\hline Chiengrai & 6,514 & 7,992 & 6,741 & 9,115 & 2,033 & 11,148 \\
\hline Phisanuloke & 2,468 & 2,776 & 2,486 & 3,654 & 259 & 3,913 \\
\hline Surat Thani & 5,442 & 11,679 & 8,929 & 5,614 & 15,280 & 20,895 \\
\hline Phuket & 18,914 & 38,283 & 31,691 & 39,583 & 155,288 & 194,871 \\
\hline Krabi & 12,140 & 15,589 & 13,803 & 12,584 & 15,033 & 27,617 \\
\hline Udon Thani & 2,233 & 2,040 & 2,226 & 3,800 & 134 & 3,934 \\
\hline Khon Kaen & 3,078 & 4,651 & 3,100 & 6,382 & 138 & 6,520 \\
\hline Nakhon Ratchasima & 2,126 & 2,589 & 2,133 & 8,334 & 159 & 8,493 \\
\hline Kanchanaburi & 1,845 & 2,976 & 1,899 & 6,555 & 523 & 7,079 \\
\hline Phetchaburi & 2,575 & 4,892 & 2,731 & 7,481 & 1,023 & 8,504 \\
\hline Prachuap Khiri Khan & 6,714 & 11,510 & 7,564 & 13,800 & 5,097 & 18,896 \\
\hline Chonburi & 6,462 & 13,649 & 10,543 & 17,153 & 47,585 & 64,737 \\
\hline Rayong & 4,469 & 8,135 & 4,726 & 13,565 & 1,861 & 15,426 \\
\hline Trad & 6,992 & 16,899 & 9,034 & 5,261 & 3,300 & 8,561 \\
\hline Total of 16 Provinces & 5,778 & 19,310 & 9,800 & 296,180 & 418,655 & 714,834 \\
\hline Whole Kingdom & 3,783 & 23,875 & 8,200 & 359,267 & 638,869 & 998,136 \\
\hline
\end{tabular}

Source. Thailand Tourism Authority and Euromonitor (2014)

\section{Contribution of Accommodation services to Tourism Industry and the Economy}

Once tourist pays money for accommodation services, the income of the local service provider will increase, and money of other related tourism sectors will also rise. Who will benefit from such initial payment of tourist depends on the effect that caused such impact. Money that is first spent by tourist for accommodation service is regarded as "direct effect". Once the money is in the hand of housing service provider, business-to-business transactions within the tourism sector will occur. The accommodation service provider who initially benefits from the direct effects will subsequently add spending to other local related tourism businesses. The indirect effect, on the other hand, is a measure of this increase in business-to-business activity.

In this study, we categorized traveling costs into 12 tourism activities. The computed percentage of accommodation cost for the 16 provinces and the whole kingdom was in Table 7 . The results showed that, in Thailand, Thai tourist spent $33.94 \%$ for accommodation services, while inbound tourist spent only $18.21 \%$ of travel budget because they had to pay air transport up to $26.45 \%$. The estimates were a little difference from Department of Tourism, who classified tourist's expenditures into six main categories, namely, accommodation, food and beverage, transport, entertainment, and sightseeing. In 2012, it was reported that the cost of 
accommodations took $31 \%$ of the total expenditures.

\subsection{The Direct Effects}

The initial amount of money spent by either domestic or foreign visitors will benefit the 12 tourism service providers regarding increase their income directly. More than half of the additional money increased was concentrated in only two sectors; Air passenger transport services $(33.94 \%)$ and Accommodation services $(18.70 \%)$.

Air service takes a lead in generating the largest share of expenditures from both domestic and international tourists. Currently, air transportation is the most convenient carrier for both local and international trips. The intensive competition of low-cost airlines makes it possible to access by a larger group of middle-income consumers. For Thailand, air transportation should be the most dynamic regarding new routes introducing in particular within AEC destinations for a period. After the rail development under Thailand's national infrastructure is implemented possibly in the next eight years, more money will go to railway passenger transport services. The rail transport is not limited just within Thailand, but also connecting to other neighboring countries to Laos, Myanmar, and Cambodia and toward China and Vietnam.

In 2013, tourism accommodation service provider earned the second largest share of money spent by an internal visitor in Thailand. The increase in demand for accommodation will benefit most to the chained hotels who take $54.06 \%$ of the total sales (Table 4 ).

For the domestic visitor, $65.33 \%$ of the additional income increased was concentrated in only three sectors; Air passenger transport services (22.10\%), Accommodation services (21.22\%), and Shopping (18.23\%). For inbound arrivals, most of their spending was for air transport, accommodation services, while shopping was not their favorite activities (Table 7).

Money earned by accommodation services provider mostly went to the chained hotel which occupied more than half of the total sales (Table 4). In the next five years, the chained hotel would still earn the biggest share in accommodation in Thailand; since the growth rate of demand for chained hotel is higher than an independent hotel (Table 5). The increasing flight frequency of low-cost carriers both domestic as well as inbound to Thailand tends to garner much interest in budget hotels from key players. There is a tendency to shift hotel portfolios from medium and high-end range into the brand economy.

Table 7. Direct and indirect effect resulting from additional demand from internal visitor in Thailand

\begin{tabular}{|c|c|c|c|c|c|c|c|c|c|}
\hline \multirow{2}{*}{ Tourism Products } & \multicolumn{3}{|c|}{$\%$ of Total Direct Impact } & \multicolumn{3}{|c|}{$\%$ of Total Indirect Impact } & \multicolumn{3}{|c|}{$\%$ of Total Impact } \\
\hline & Domestic & Inbound & Total & Domesti & Inbound & Total & Domestic & Inbound & Total \\
\hline Accommodation services & 21.22 & 17.09 & 18.70 & 26.62 & 23.12 & 24.55 & 24.38 & 20.51 & 22.07 \\
\hline Shopping products & 18.23 & 9.13 & 12.69 & 9.85 & 5.32 & 7.17 & 13.32 & 6.97 & 9.52 \\
\hline Air passenger transport services & 22.10 & 41.54 & 33.94 & 14.37 & 29.14 & 23.10 & 17.57 & 34.50 & 27.70 \\
\hline Other 9 sectors & 38.45 & 32.24 & 34.67 & 49.16 & 42.42 & 45.18 & 44.73 & 38.02 & 40.71 \\
\hline Total Tourist's Expenditures (bil. Baht) & 597.40 & 930.31 & $1,527.71$ & 846.01 & $1,221.54$ & $2,067.55$ & $1,443.41$ & $2,151.84$ & $3,595.26$ \\
\hline Total Tourist's Expenditures (bil. USD) & 19.22 & 29.93 & 49.15 & 27.22 & 39.30 & 66.52 & 46.44 & 69.23 & 115.67 \\
\hline
\end{tabular}

\subsection{The Indirect Effect and Total Effect}

Once accommodation service providers received money paid by tourists, the money will be recirculated to other tourism activities; the benefit will be spilled over to the tourism industry and finally to the Thai economy. Table 7 illustrated how the money flowed to the 12 tourism activities as the indirect effect. Table 8 showed that the initial amount of 9.19 billion USD paid to accommodation services increased by 2.78 to the total amount of 25.52 billion USD, generating 16.33 billion USD through the indirect effect.

For the computation of total effect, the results in Table 7 showed that the "Tourism accommodation services" sector in Thailand was the second largest contributor to the tourism industry after "Air passenger transport services." According to the information from conducting the focus group in 16 provinces, it is found that among the 12 tourism activities, the "Accommodation service" have the highest linkage within the sector. Examples of connectivity within accommodation sector were sharing rooms in case of facing too crowded customers or sharing meeting room services. For other tourism activities that had high linkage with accommodation services 
were "Food and beverage serving activities" and "Road passenger transport services". The hotels tended to buy food and bakery from outside suppliers. The tourists especially foreigners tend to fly from one city and rent a car; with or without a driver, at the destination going to another area within or outside the city.

Table 8. Income generating from accommodation services activities

\begin{tabular}{|c|c|c|c|c|c|c|c|c|c|}
\hline \multirow{2}{*}{$\begin{array}{c}\text { Accommodation } \\
\text { services }\end{array}$} & \multicolumn{3}{|c|}{$\%$ of Total Direct Impact } & \multicolumn{3}{|c|}{$\%$ of Total Indirect Impact } & \multicolumn{3}{|c|}{$\%$ of Total Impact } \\
\hline & Domestic & Inbound & Total & Domestic & Inbound & Total & Domestic & Inbound & Total \\
\hline Billion Baht & 126.77 & 158.96 & 285.73 & 225.19 & 282.39 & 507.58 & 351.96 & 441.35 & 793.31 \\
\hline Billion USD & 4.08 & 5.11 & 9.19 & 7.25 & 9.08 & 16.33 & 11.32 & 14.20 & 25.52 \\
\hline
\end{tabular}

Upon comparing the 16 top tourist earners in Thailand, Table 9 illustrated that accommodation services provider in Bangkok were the top recipient in Thailand. The second most gainer from accommodation sector was Phuket; the biggest and the second most popular tourist destination for a foreigner in Thailand. Chonburi with the popular Pattaya Beach was the third favorite location to stay for foreign tourist after Bangkok and Phuket.

Table 9. Percentage of income generating from accommodation services activities categorized by destination

\begin{tabular}{|c|c|c|c|c|c|c|c|c|c|}
\hline \multirow{2}{*}{ Destination } & \multicolumn{3}{|c|}{$\%$ of Total Direct Impact } & \multicolumn{3}{|c|}{$\%$ of Total Indirect Impact } & \multicolumn{3}{|c|}{$\%$ of Total Impact } \\
\hline & Domestic & Inbound & Total & Domestic & Inbound & Total & Domestic & Inbound & Total \\
\hline Bangkok & 20.66 & 27.25 & 24.33 & 19.08 & 25.17 & 22.47 & 19.65 & 25.92 & 23.14 \\
\hline Chiengmai & 4.09 & 1.25 & 2.51 & 4.64 & 1.42 & 2.85 & 4.44 & 1.36 & 2.73 \\
\hline Chiengrai & 1.56 & 0.29 & 0.85 & 1.68 & 0.31 & 0.92 & 1.63 & 0.30 & 0.89 \\
\hline Phisanuloke & 0.55 & 0.04 & 0.26 & 0.62 & 0.05 & 0.30 & 0.59 & 0.04 & 0.29 \\
\hline Surat Thani & 1.16 & 1.75 & 1.49 & 1.04 & 1.58 & 1.34 & 1.08 & 1.64 & 1.39 \\
\hline Phuket & 5.21 & 12.04 & 9.01 & 5.48 & 12.66 & 9.47 & 5.38 & 12.43 & 9.30 \\
\hline Krabi & 2.20 & 2.18 & 2.19 & 2.11 & 2.09 & 2.10 & 2.14 & 2.12 & 2.13 \\
\hline Udon Thani & 0.65 & 0.02 & 0.30 & 0.67 & 0.02 & 0.31 & 0.66 & 0.02 & 0.30 \\
\hline Khon Kaen & 0.83 & 0.02 & 0.37 & 0.99 & 0.02 & 0.45 & 0.93 & 0.02 & 0.42 \\
\hline Nakhon Ratchasima & 0.87 & 0.02 & 0.40 & 1.09 & 0.02 & 0.49 & 1.01 & 0.02 & 0.46 \\
\hline Kanchanaburi & 0.49 & 0.08 & 0.26 & 0.56 & 0.09 & 0.30 & 0.53 & 0.08 & 0.28 \\
\hline Phetchaburi & 0.82 & 0.12 & 0.43 & 0.88 & 0.13 & 0.46 & 0.86 & 0.12 & 0.45 \\
\hline Prachuap Khiri Khan & 2.63 & 0.58 & 1.49 & 2.82 & 0.62 & 1.60 & 2.75 & 0.60 & 1.56 \\
\hline Chonburi & 2.07 & 6.92 & 4.77 & 2.21 & 7.37 & 5.08 & 2.16 & 7.21 & 4.97 \\
\hline Rayong & 2.64 & 0.36 & 1.37 & 2.71 & 0.37 & 1.41 & 2.68 & 0.37 & 1.40 \\
\hline Trad & 1.16 & 0.68 & 0.89 & 1.41 & 0.83 & 1.09 & 1.32 & 0.78 & 1.02 \\
\hline $\begin{array}{l}\text { Total of } 16 \text { Provinces } \\
\text { (mil. USD.) }\end{array}$ & 1,941 & 2,740 & 4,681 & 3,476 & 4,790 & 8,266 & 5,417 & 7,530 & 12,947 \\
\hline $\begin{array}{l}\text { Whole Kingdom } \\
\text { (mil. USD.) }\end{array}$ & 4,078 & 5,114 & 9,193 & 7,245 & 9,085 & 16,330 & 11,323 & 14,199 & 25,522 \\
\hline
\end{tabular}

\section{Conclusion and Policy Implications}

The rising number of arrivals pushed up the high demand for travel accommodation in Thailand. This paper calculates the impacts of tourist spending on lodging and other inter-related tourism services for Thailand by using the "Tourism I-O Table for Thailand (NIDA 2013) developed for this study.

Accommodation service is regarded as an outlet to create revenue for people in the communities and lifts up their standard of living. Results of the survey show that money generated from indirect effect increase by 2.78 of the initial amount paid by visitors from the direct effect.

Accommodation sector in Thailand still has promising future for further development because the ratio of tourist to excursionist is greater than 1. Even though tourism accommodation service providers earned the second largest share of money spent by the internal visitor in Thailand after "Air passenger transport services", local service provider earn only one-fourth of the total sales; since the accommodation sector in Thailand is not well organized. The chained international hotel dominates the sales performance of hotels in Thailand. Other types of 
accommodation are very fragmented, usually operated by local players, and play an only minor role in the sector. Among the ten countries studied, South Korea and Australia can be a good example of accommodation structure that benefits local accommodation business, where the motels in Korea play the biggest share, and in Australia, the private accommodation earns the highest sale among other travel accommodation.

\section{References}

A Data Collection of Business and Government Agencies for Constructing Thailand's Tourism Satellite Accounts (TSA) 2013. (2014). Faculty of Development Economics, National Institute of Development and Administration, Bangkok, Thailand. (in Thai)

Australian Bureau of Statistics. (2011). Australian National Accounts: Tourism Satellite Account, 2010-11. Cat. No. 5249.0, Canberra. Retrieved from http://www.abs.gov.au/ausstats/abs@.nsf/mf/5249.0

Euromonitor International. (2014). Travel Accommodation. Passport. Retrieved from http://www.euromonitor. com/countries. (various countries).

Eurostat. (2009). Tourism Satellite Accounts in the European Union Volume 1: Report on the implementation of TSA in 27 EU Member States. Luxembourg: Office for Official Publications of the European Communities. Retrieved from http://ec.eyrioa.eu

Eurostat. (2008). Background document Thirty-ninth session, 26 - 29 February 2008, jointly presented by the United Nations Statistics Division (UNSD), the Statistical Office of the European Communities (EUROSTAT), the Organisation for Economic Co-operation and Development (OECD) and the World Tourism Organization (UNWTO). Retrieved from http://ec.europa.eu/eurostat

Frechtling, D. C., \& Horvath, E. (1999). Estimating the Multiplier Effects of Tourism Expenditures on a Local Economy through a Regional Input-Output Model. Journal of Travel Research, 37, 324-332.

Johnpaul, E. (2015). Accommodation a Vital Component in Tourism Industry. Retrieved from http://enugustatetourismboard.com/p.php?t=accommodation-a-vital-component-in-touri\&id=51

Kemp, K., \& Nijhowne, S. (2004). Study of the Canadian Tourism Satellite Account (CTSA): Comparison of TSA-RMF and CTSA. Phase I, Final Report, Canadian Tourism Commission for Macroeconomic and Statistics Sub-Committee of the World Tourism Organization. June 2004. Retrieved from https://books.google.co.th/books?id=UrckjwEACAAJ\&dq=Canadian+tourism+satellite+account\&hl=en\&s $\mathrm{a}=$ X\&ved=0ahUKEwisu-yi_eLMAhUIM48KHZJVBw0Q6AEIIDAB

The Alaska Tourism Satellite Account. (2004). A Comprehensive Analysis of the Economic Contribution of Travel and Tourism. Alaska Department. Retrieved from https://books.google.co.th/books?id=T8Qr AQAAMAAJ\&q $=$ The + Alaska + Tourism + Satellite + Account\&dq $=$ The + Alaska + Tourism + Satellite + Account \&hl=en\&sa=X\&ved=0ahUKEwiqu8C-gOPMAhUEro8KHaCmDF0Q6AEIIzAA

Vora-Sittha, P., Silaprachawong, U., \& Watanakuljarus, A. (2015). A Study of Non-Monetary Indicators of Thai Tourism Industry for Constructing Thailand's Tourism Satellite Accounts. Center for AEC Capability Research, Research Center, National Institute of Development and Administration, Thailand. (in Thai).

Watanakuljarus, A., Vora-Sittha, P., \& Silaprachawong, U. (2013). A Data Collection for Thailand's Tourism Satellite Accounts (TSA) 2013. Faculty of Development Economics, National Institute of Development and Administration, Bangkok, Thailand. (in Thai)

Weisbrod, G., \& Weisbrod, B. (1997). Measuring Economic Impacts of Projects and Programs (PDF). Economic Development Research, Group 2.

World Travel and Tourism Council (WTTC). (2008). Tourism Satellite Accounts (TSA), Regional and Country Reports: The 2008 Travel \& Tourism Economic Research - Thailand. Retrieved from http://www.wttc.org/

World Travel and Tourism Council. (2014). Travel \& Tourism Economic Impact 2014 Thailand. The Authority on World Travel \& Tourism. Retrieved from http://www.wttc.org/research/economic-research/economicimpact-analysis/

\section{Copyrights}

Copyright for this article is retained by the author(s), with first publication rights granted to the journal.

This is an open-access article distributed under the terms and conditions of the Creative Commons Attribution license (http://creativecommons.org/licenses/by/3.0/) 